\title{
Management Model of Mambal Irrigation Area in the Efforts to Develop Environment-Based Agro-tourism
}

\author{
I Gusti Agung Putu Eryani ${ }^{1, a)}$, A.A.Sg. Dewi Rahadiani ${ }^{1)}$ \& Cok Agung Yujana ${ }^{1)}$ \\ ${ }^{1)}$ Civil Engineering Department, Warmadewa University, Denpasar, Bali \\ Correspondent : ${ }^{a}$ eryaniagung@gmail.com
}

\begin{abstract}
Bali has an irrigation system known as Subak. The utilization and operation of Subak, are carried out by involving community participation in it. Mambal Irrigation Area, having great water potential, can still be developed to increase agricultural yields in the Mambal Irrigation Area. The purpose of this research was to determine the management model of the Mambal Irrigation Area to develop agro-tourism with environment-based. The SWOT model, based on the potential and problems that occur in the Mambal Irrigation Area, is used. Based on the location survey and SWOT analysis, the results obtained are the strength of the Mambal Potential water in the Mambal weir can flow during the dry season and rainy season, this potential can be used to increase agricultural yield and develop the area as an agro-tourism environment-based. But on the other hand there are still some problems that occur in the Mambal Irrigation Area. Alternative management, can be done to optimize the existing potential and reduce the negative impact due to existing problems, is by developing environment-based agro-tourism in the Mambal Irrigation Area. Agro-tourism is expected to reduce the land-use change in the Subak area, improve socio-economic conditions in the surrounding area, and can maintain the environmental sustainability.
\end{abstract}

Keywords : infrastructure management, irrigation area, agro-tourism, subak.

\section{INTRODUCTION}

Bali is one of the provinces in Indonesia that still maintains its agrarian culture. Irrigation areas in Bali are managed by Subak. The normative understanding of Subak can be found in Bali Provincial Regulation Number 9 of 2012 concerning Subak (Perda Bali No 9, 2012). In this regulation, Subak is defined as a traditional organization in the field of water use and or plant management at the level of farming in indigenous communities in Bali. Subak is a socioagrarian, religious, economic organization that has historically continued to grow and develop.

Subak was designated by UNESCO as World Cultural Heritage on 29 June 2012 under the label Cultural Landscape of Bali Province: the Subak System as a Manifestation of the Tri Hita Karana Philosophy (Ministry of Culture and Tourism, 2011). Determination of Subak as World Cultural Heritage (WBD) is the pride of the Balinese people in particular, and the Indonesian people in general (Windia and Wiguna, 2013).

Nowadays, the area of agricultural land in Bali has decreased due to land conversion. Judging from the resources of paddy fields, many productive paddy fields have been converted into housing, industry, tourism, and for other purposes. On the other hand, the formation of new paddy fields to replace lost paddy fields requires high costs and a long time due to limited supporting infrastructures such as connecting roads, irrigation infrastructure, and transportation (Santosa, 2008). Wiguna (2008) states that the area of paddy fields in Bali is always decreasing, which reaches an average of 1,000 ha per year, due to the conversion of agricultural land to non-agricultural land, mainly due to the development of the tourism sector (Wiguna, 2008). In 
line with Windia who states that the conversion of agricultural land over the past five years has reached 5,000 hectares, or an average of 1,000 hectares each year.

Mambal Irrigation Area is one of the Ayung River Basin irrigation areas that have enormous potential, both in terms of water potential and tourism potential. Mambal irrigation area is located in Mambal village, Badung Regency. Even though it has great potential, according to Santosa (2010), the area of paddy fields in the Mambal Irrigation Area up to the 80 s was recorded at 4820 ha and then it shrank every year. In 2008, the area of agriculture land was merely around 2980 ha. It can be said that within 30 years, the area of agriculture land shrank 38.17\% (Santosa et al, 2010). If it is maintained and developed, the Mambal Irrigation Area can be developed as a tourism area, that capable to increase the region's income, and also be a step in maintaining the food security of the Bali Province in general and Badung Regency in particular.

Farmers as the main actors, with the capital of simplicity and the uniqueness of daily life and cultural customs, can be a good attraction for tourism, so farmers will get added value in their economic life. Through this approach, it is hoped that tourism development will be more acceptable and be able to provide economic, socio-cultural, and environmental benefits. Agrotourism is a model of tourism development that is closely related to agriculture.

Agrotourism is an alternative form of tourism in Bali. Agrotourism is a specific form of rural tourism with a close relation to nature and countryside of rural areas and a direct relationship to agricultural activities (Joshi, P.V. \& Bhujbal, 2012). Agrotourism is the development of agriculture-based tourism, by utilizing agricultural activities such as plowing, planting rice, and harvesting as tourist attractions. Besides the use of agricultural products such as rice, vegetables, and fruit for the needs of the tourism industry such as hotels and restaurants in a tourist destination is also part of the development of agro-tourism (Herawati, 2015).

Based on the potential and problems that occur in the Mambal Irrigation Area, an irrigation area management model to develop agro-tourism is needed. With this management model, it is expected to maintain the sustainability of agricultural areas in the Mambal Irrigation Area that can have an impact on food security and can reduce the land-use change that occurs in the mambal irrigation area. Then on the tourism side, it also capable to improve the economic level in the area.

\section{RESEARCH METHODS}

\section{Research Location}

This research took place in the Mambal Irrigation Area located in Mambal Village, Abiansemal District, Badung Regency.

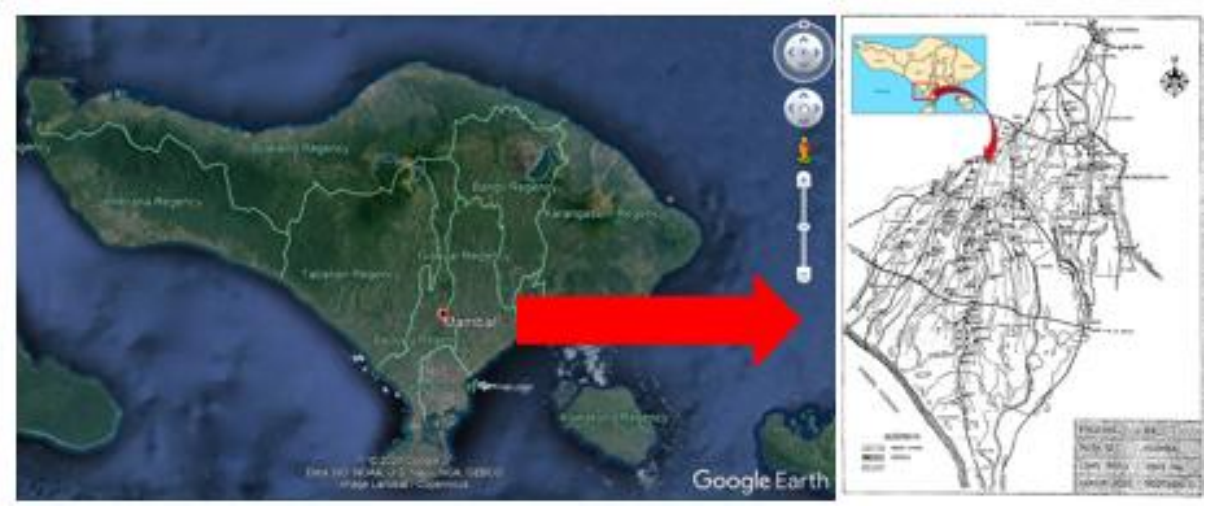

Picture 1. Map of Mambal Irrigation Area

Source: (Mambal Irrigation Area Dam Observers Office, 2018) 


\section{Research Data}

The data used in this study are primary data and secondary data. Primary data is obtained based on direct observations to the Mambal Irrigation Area to determine existing conditions and problems that occur. Secondary data were obtained from data on the conditions and potential of the Mambal Irrigation Area.

\section{Data Analysis Technique}

This research is a qualitative study, by creating a SWOT model to find out the management model of the Mambal Irrigation Area which will be developed into an environment-based agro-tourism area. So that it can have a positive impact on the Mambal Irrigation Area and the surrounding area.

According to Kotler (2000), SWOT analysis (strengths, weaknesses, opportunities, threats) is an overall evaluation of strengths, weaknesses, opportunities, and threats. The benefits of SWOT analysis are to increase organizational knowledge and understanding so that they can analyze what are the strengths, weaknesses, opportunities, and threats in the organization to get the right strategy by using existing strengths and opportunities to overcome all threats and reduce existing weaknesses so that the organization can survive and be able to develop (Kotler, 2000).

According to Riadi (2013), the SWOT analysis has the function of obtaining information from situations, analysis, and separating it into internal issues (strengths and weaknesses) and external issues (opportunities and threats) (Riadi, 2013).

\section{RESULTS AND DISCUSSION}

\section{General Overview of Mambal Irrigation Area}

The Mambal Irrigation Area gets water from the Mambal weir. Water from the Mambal weir has been distributed to 43 subaks located in 3 districts that are Denpasar, Badung, and Tabanan. The utilization of water in the Mambal Weir itself has been channeled to rice plants with an area of rice plants flowing reaching $3845 \mathrm{Ha}$. The irrigation system itself uses a flushing system.

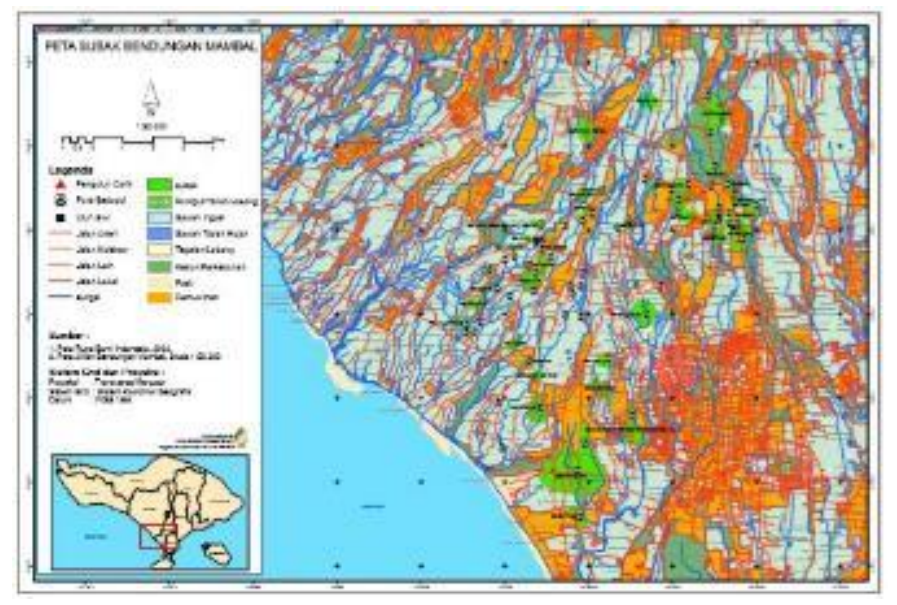

Picture 2. Map of Mambal Irrigation Area

Source: (Mambal Irrigation Area Dam Observers Office, 2018)

\section{Potential Water of Mambal Weir}

At the time of the survey conducted in November the water discharge in the Mambal Weir amounted to $11,545 \mathrm{l} / \mathrm{sec}$. The water is planned to be distributed to 43 subaks in 3 regencies, 
where Denpasar Regency has 9 subaks, 9 subaks in Badung, 1 subak in Tabanan Regency, and with a total standard area of 5963 hectares.

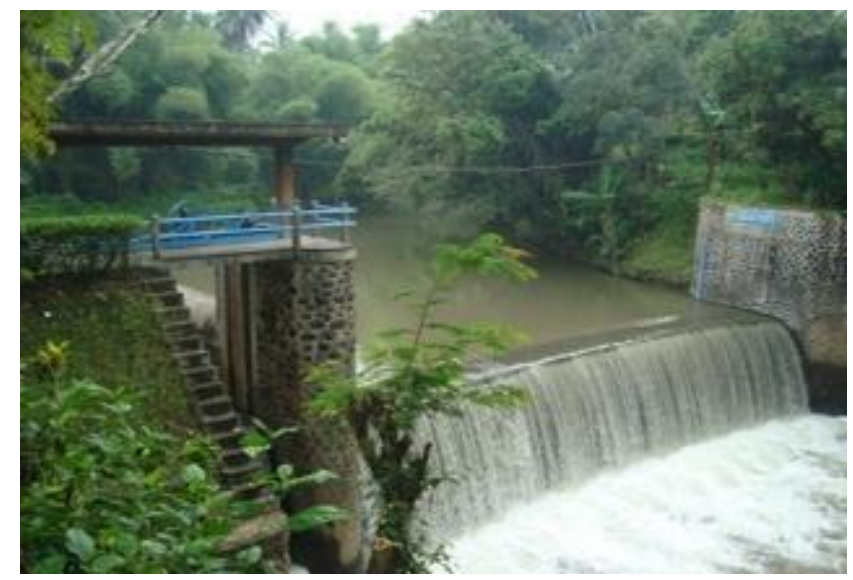

Picture 3. Mambal Weir

Source: (CV. Amertha Nirwana, 2018)

\section{Tourism Potential of Mambal Irrigation Area}

Mambal Irrigation Area has a view of rice fields that stretches wide and still have cool weather that can be used as a tourist attraction for tourists who have a busy activity that makes tired on weekdays. If it is developed into an agro-tourism area, this can reduce the conversion of paddy fields to settlements or hotels.

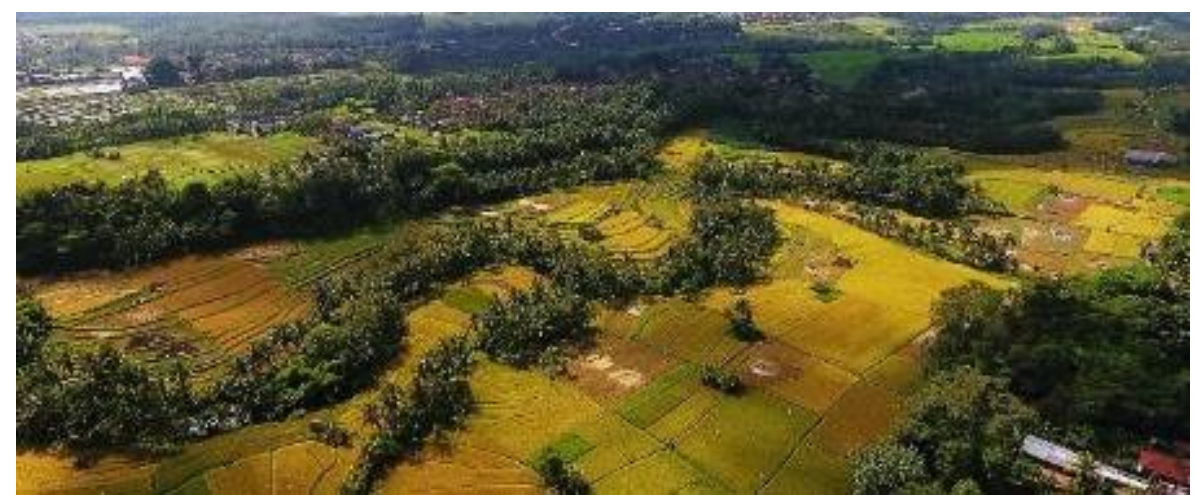

Picture 4. Natural Landscape in the Mambal Irrigation Area

Agricultural activities and related to the Subak system, which can be used as a tourist commodity include plowing using cattle or buffalo. Tourists can enjoy the elements of nature and agricultural activities in tourist activities that provide a new experience for tourists. Rice planting carried out by tourists can also be a new experience for a tourist, so that it is in line with the principles of agro-tourism development that prioritizes an experience as a tourism product. After they spend the energy to get the new experience, then tourists can be served with soft drinks in the form of young coconut water which most likely they have never enjoyed in their home country. The attraction of processing and transporting organic fertilizer derived from livestock waste can also be used as one of the agricultural tourism attractions related to the Subak system. Traditional local rice harvest by a farmer is also one of the potential tourist attractions that have been developed by the subak Mambal irrigation community.

\section{Land Use Change in Mambal Irrigation Area}

Conversion of agricultural land is not just happening in the rural areas of urban land conversion occurred, especially too much in villages that have high connectivity to the city center. Location factors determine the shape of the land conversion form a person will also 
make use of land belonging to the appropriate underlying interests. Conversion of agricultural land is directly or indirectly will affect the condition of the physical, social, and economic issues for the residents and the environment (Harini et al, 2013).

The area of paddy fields in Sempidi Subak before the conversion of land, in the year before 2003 was 135 ha. Furthermore, up to 2008 the area was still available for 99 ha, or in the last five years the land had shrunk by around $26 \%$.

On the contrary, the flow of irrigation water serving agricultural activities in Sempidi Subak increased, especially in 2008. Thus it can be said that there was an increase in irrigation water services from an average of 1.70 liters/second/ha in the range of 2005-2007 to 2.14 liters/second/ha (Santosa et al, 2010).
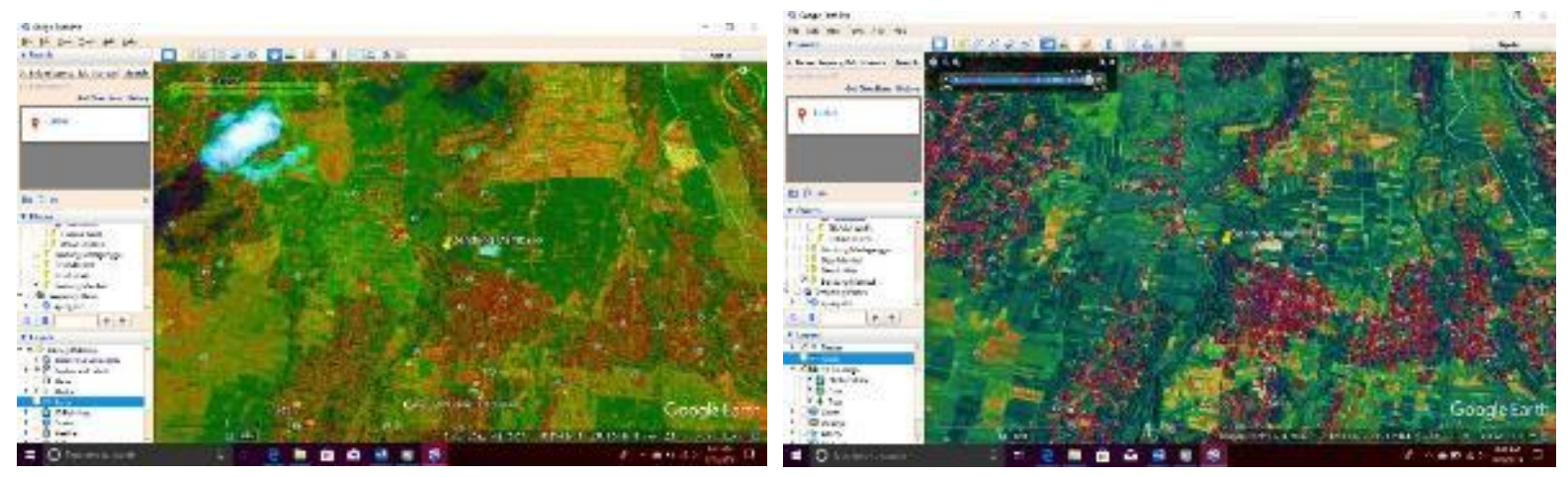

Picture 5. Changes in Mambal Irrigation Area conditions in 2005 and 2018 (Source: Google Earth)

Aerial images obtained from Google Earth Pro from 2005 to 2018 saw that there has been a change in land use in the Mambal irrigation area, wherein 2018 residential areas in the Mambal Irrigation Area have increased.

\section{Technical Problems in Mambal Weir}

1. Damage in the Channel Wall

Based on the results of field observations, damage occurred on the walls of irrigation channels in several locations. The damage was relatively small and tended not to significantly affect the process of water flow, but if left unchecked the damage would be more severe and result in landslides at the edges of the channel. The damage is usually caused by high water discharge during the rainy season and also the age factor of the building.

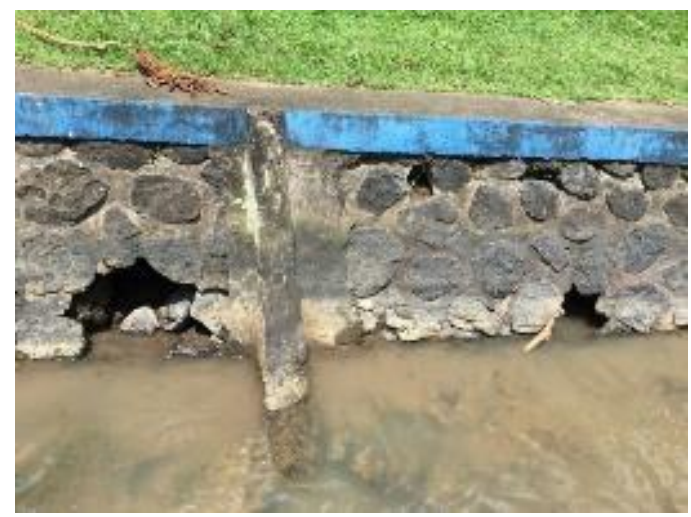

Picture 6. Channel Wall Damage Due to Erosion

2. Trash Pollution

Human resources are the main factor to achieve irrigation success. The low level of awareness of the surrounding community to care for, protect the environment, causes 
problems with the buildup of trash in the canal, this can make water flow obstructed even if left unchecked will cause flooding in the rainy season. Trash pollution in water bodies has been widespread and caused serious consequences for the ecosystem and livelihood of people. In terms of water quality control, trash generated from human activities might be identified as litter, debris, rubbish, or refuse (Moore et al., 2016).

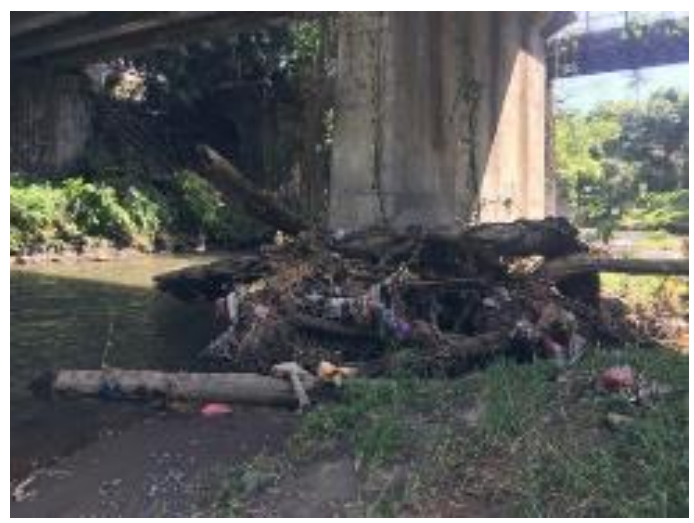

Picture 7. Trash Stacking in Irrigation Channels

\section{SWOT Model of Mambal Irrigation Area Management as Environment-Based Agrotourism}

Irrigation management is a systematic approach to plan, construct, to operate, and to maintain an irrigation system, aims at increasing and maintaining irrigated agriculture productivity (Suprayitno \& Soemitro, 2018).

Based on the potential and existing conditions in the Mambal irrigation area, a SWOT model can be developed based on Strength, Weakness, Opportunity, and Threat as follows.

1. Strength (S)

- Large water potential

- Fascinating Subak natural scenes

- Farming activities are going well

- Reachable

- Strong social norms (awig-awig)

- There is already a water user organization

2. Weakness (W)

- Tourist attractions are not well developed

- There is still damage in the Mambal weir building

- The variation of tourist attractions is still limited

- There is no widespread marketing

- Subak is not yet able to provide supporting tourism facilities

- Transfer of land functions because they are considered ownership rights

- Much of the transformation of the workforce outside the agricultural sector

3. Opportunity $(\mathrm{O})$

- The tourist market is very large

- There is government support because it is in line with the vision of developing cultural tourism

- The natural landscape can be a cheap and promising tour

- Agro-tourism can be used as a recreation area

- Large water potential can increase agricultural output

- Can reduce land-use change 


\section{Threat $(\mathrm{T})$}

- Lack of public appreciation of the tourist attraction of Subak

- Development of facilities threatens Subak land

- Entrepreneurs see the tourist attraction of the Mambal Irrigation Area as a mere business area, with a lack of concern for environmental sustainability

- The greater level of land-use change

Based on strengths, weaknesses, opportunities, and threats, several strategies can be carried out in managing the Mambal irrigation area as environment-based agro-tourism, including the following.

1. SO Strategy

(Using the strength to take advantage of opportunities)

- Promote Mambal agro-tourism with government assistance

- Maximizing agricultural output by utilizing the great water potential

- Organize shows about local agricultural (subak) culture with the participation of subak organizations to increase the interest of the surrounding society to preserve subak

2. WO Strategy

(Minimize weaknesses to take advantage of opportunities)

- Begins to invite the surrounding community to participate in the development of agrotourism

- Repair damage to the Mambal irrigation canal so that water losses that occur can be reduced and can maximize agricultural output

- Begin to develop tourist attractions such as outbound, recreation, or outing.

3. ST Strategy

(Using strength to overcome threats)

- Develop environmental-based agro-tourism so that in addition to reducing land-use change, it can maintain environmental sustainability, so that natural atmosphere which is a tourist attraction is maintained

- Use existing rules or norms to limit tourism development that leads to land-use change

4. WT Strategy

(Minimize weaknesses to avoid threats)

- Add tourist attractions in the Mambal Irrigation Area to increase the appreciation of the surrounding community towards the tourist attraction of the Mambal Irrigation Area

- Increase the maintenance of Mambal Weir by including community participation

- Protecting the environment around the irrigation area patch with community participation so that it can reduce the desire to carry out the land-use change

\section{CONCLUSION}

Based on the SWOT model created, it can be concluded that there are several strategies in managing Mambal Irrigation Areas as an environment-based agrotourism including the following.

- Promote Mambal Agro-Tourism with government assistance

- Maximizing agricultural output by utilizing the great water potential

- Organize shows about local agricultural (subak) culture with the participation of subak organizations to increase the interest of the surrounding society to preserve subak

- Begins to invite the surrounding community to participate in the development of agrotourism 
- Repair damage to the irrigation canal mambal so that water losses that occur can be reduced and can maximize agricultural output

- Begin to develop tourist attractions such as outbound, recreation, or outing.

- Develop environmental-based agro-tourism so that in addition to reducing land-use change, it can maintain environmental sustainability, so that the natural atmosphere which is a tourist attraction is maintained

- Use existing rules or norms to limit tourism development that leads to land-use change

- Add tourist attractions in the Mambal irrigation area to increase the appreciation of the surrounding community towards the tourist attraction of the Mambal irrigation area

- Increase the maintenance of Mambal Weir by including community participation

- Protecting the environment around the irrigation area patch with community participation so that it can reduce the desire to carry out the land-use change

\section{ACKNOWLEDGMENT.}

Acknowledgments submitted to the Warmadewa University who have supported the completion of this paper.

\section{REFERENCES}

Bali Government (2012) Peraturan Daerah Provinsi Bali Nomor 9 Tahun 2012. Indonesia. Available at: https://jdih.baliprov.go.id/produk-hukum/peraturan/20404.

CV. Amertha Nirwana (2018) Preliminary Report on Inventory and Condition of Irrigation Networks in the Tukad Ayung River Basin in the Province of Bali. Denpasar.

Harini, R., H.S. Yunus., Kasto, \& S. H. (2013) 'Agricultural Land Conversion: Determinants and Impact for Food Sufficiency in Sleman Regency', Indonesian Journal of Geography, 44(2), pp. 120-133. DOI: 10.22146/indo.j.geog,2394.

Herawati, N. (2015) 'Pengembangan Pariwisata Berkelanjutan Berbasis Subak Sebagai Bagian Warisan Budaya Dunia Unesco di Desa Mengesta Kabupaten Tabanan', Jurnal Master Pariwisata (JUMPA), 2(1), pp. 79-103. DOI: 10.24843/jumpa.2015.v02.i01.p05.

Joshi, P.V. \& Bhujbal, M. B. (2012) 'Agro-Tourism a Specialized Rural Tourism: Innovative Product of Rural Market', International Journal of Business and Management Tomorrow, 2(1), pp. 1-12.

Kotler, P. (2000) Marketing Management. Prenhallindo: Jakarta.

Mambal Irrigation Area Dam Observers Office (2018) Map of Subak Mambal. Badung.

Ministry of Culture and Tourism (2011) 'Nomination for inscriptions on the UNESCO World Heritage List', in Cultural Landscape of Bali Province. Ministry of Culture and Tourism of the Republic of Indonesia: Jakarta. Available at: http://whc.unesco.org/uploads/nominations/1194rev.pdf.

Moore, S. et al. (2016) Southern California Bight 2013 Regional Monitoring Program: Volume III. Trash and Marine Debris. DOI: 10.13140/RG.2.2.32214.04163.

Riadi, M. (2013) Strength Weakness Opportunities Threats (SWOT), kajianpustaka.com. Available at: http://www.kajianpustaka.com (Accessed: 4 August 2019).

Santosa, I., Adnyana, G., Dinata, I., \& Gunadi, I. (2010) 'Impact of Changing Function of Rice Fields on Utilization of Water Resources to Support Food Security', Bumi Lestari Journal Of Environment, 10(2), pp. 208-214. Available at: https://ojs.unud.ac.id/index.php/blje/article/view/123/105.

Santosa, I. G. N. (2008) 'Conservation of Water Resources as the Key to Realize Sustainable Water Use, Food Security and Poverty Alleviation', in The 5th INWEPF Steering Meeting. Symposium on Efficient and Sustainable Water Use to Address Poverty Alleviation and Food Security. INWEPF Indonesian Committee: Bali, pp. 151-156. 
Suprayitno, H. \& Soemitro, R. A. . (2018) 'Preliminary Reflexion on Basic Principle of Infrastructure Asset Management Pemikiran Awal tentang Prinsip Dasar Manajemen Aset Infrastruktur', Jurnal Manajemen Aset Infrastruktur \& Fasilitas, 2(1), pp. 1-10.

Wiguna, I. W. A. A. (2008) The Versatility of the Subak Ecosystem in Tourism Development in Bali. I. Aksara Indonesia: Yogyakarta.

Windia, I. W., \& Wiguna, W. A. A. (2013) Subak World Cultural Heritage. Udayana University Press: Denpasar. 
(e)ISSN 2656-8896 (p)ISSN 2656-890X

Journal of Infrastructure and Facility Asset Management - Vol. 2, Issue. 2, September 2020 